\title{
Thinness among the Rural Primary School Children of Bali Gram Panchayat, Arambag, Hooghly District, West Bengal, India
}

\author{
Gopal Chandra Mandal
}

\author{
Associate Professor in Anthropology, Bangabasi College, Kolkata, India
}

\begin{abstract}
Background: Primary school age is a dynamic period of physical growth and mental development of the child. Research indicates that nutritional deficiencies and poor health in primary school age children are among the causes of low school enrolment, high absenteeism, early dropout and poor classroom performance. Chronic undernutrition is linked to slower cognitive development and serious health impairments later in life that reduce the quality of life. The thinness (low BMI for age) may be one of the tool to measure the level of undernutrition.

Objective: The objective of the present study was to assess the different grades of thinness by using age and sex specific cut off values based on body mass index (BMI).

Materials and Methods: The present cross-sectional study was conducted at Bali-Gram Panchayat, Arambagh, West Bengal, India. The data were collected from 618 rural Bengalee primary school children comprising of both boys (304) and girls (314) within the age group 5-11 years. The measurements (height in $\mathrm{cm}$. and weight in $\mathrm{kg}$ ) were taken following standard methods Thinness was evaluated using the age and sex specific cut-off points of BMI.

Results: The overall (age combined) prevalence of thinness among the boys was slightly higher (83.2\%) in comparison to the prevalence of thinness among the girls (81.5\%). The prevalence of thinness was higher in case of lower age group children among both boys and girls and it gradually decreases with the increase of age. The rate of grade III thinness $(30.5 \%)$ was greater among the girls than others while among the boys it was higher in grade I (32.9\%) category. It indicates the severity of thinness was much more among the girls than the boys. Although there was no significant sex difference between the two sexes.

Conclusion: The prevalence of undernutrition as measured by thinness was significantly higher than the national level scenario. In spite of the Mid Day Meal scheme which is running for more than 20 years, the result is dissatisfactory. The competent authority should look into the matter seriously for better nutritional and health condition of the children.
\end{abstract}

Keywords: Rural, Primary school children, BMI, thinness, undernutrition, India.

\section{INTRODUCTION}

Undernutrition in childhood was and is one of the reasons behind the high child mortality rate in developing countries. It is also highly detrimental for health in those children who survive to adulthood [1]. The enhanced survival may be simply adding to the pool of undernourished children causing severe handicaps to future human resources. Chronic undernutrition is linked to slower cognitive development and serious health impairments later in life that reduce the quality of life [2]. The majority of deaths (89\%) associated with malnutrition occur in children who are malnourished [1]. India has adopted a multidimensional strategy to combat these problems and to improve the nutritional status of the population [3]. The nutritional status of the people is increasingly being recognized world over as an important indicator of development of a country. The strength of a nation in future will be determined by how healthy and educated its people are. Prompting optimum development of the child is the responsibility of every one [4]. Primary

*Address correspondence to this author at the Associate Professor in Anthropology, Bangabasi College, Kolkata, India; Tel: 91-9433773205;

E-mail: golmal_anth@rediffmail.com school age is a dynamic period of physical growth and mental development of the child. Research indicates that nutritional deficiencies and poor health in primary school age children are among the causes of low school enrolment, high absenteeism, early dropout and poor classroom performance [5].

According to World Health Organization, the ultimate intention of the Nutritional Assessment is to improve human health [5]. A healthy child will become a healthy adult. A healthy adult will be the backbone of the society as well as the country. Body Mass Index (BMI) has been widely used for assessing nutritional status of adults [6] and thinness in adolescents and more recently in children aged 0-5 years [7]. Recently international cut off points for thinness (low BMI for age) has been established and graded as severe (III), moderate (II) and mild (I) similar to the chronic energy deficiency (CED) for adults [8].

Considering the aboe, the aim of the present study was to assess the different grades of thinness by using age and sex specific cut off values based on body mass index (BMI). 


\section{MATERIALS AND METHODS}

The present cross-sectional study was conducted at primary schools under Bali-Gram Panchayat, Arambag, situated approximately $100 \mathrm{Km}$. away from the capital of West Bengal, India. The data were collected from 618 rural Bengalee primary school children comprising of both boys (304) and girls (314) within the age group 5-11 years (Table 1 ). Information on a number of nonanthropometric variables such as - date of birth, age and sex, were collected directly from the school register. Most of the families to which the children belonged, depended upon agriculture or daily labour for their livelihood. From the schools, children were given a daily food supplementation, in the form Mid Day Meal, consisting of rice, pulses, vegetables, and egg on some days. The measurements (height in $\mathrm{cm}$. and weight in $\mathrm{kg}$ ) were taken following standard methods [9] by the author. The BMI was computed following internationally accepted standard equation as weight in $\mathrm{kg}$ divided by square of height in meter $\left(\mathrm{wt} / \mathrm{ht}^{2}\right)$. Nutritional status was evaluated using the age and sex specific cut-off points of BMI (Table 2) as described by
Cole and others [8]. Technical errors of measurements (TEM) were found to be within reference values [10] and thus not incorporated in statistical analyses. One way ANNOVA was done to test the impact of age on thinness. The $x^{2}$ test $(2 \times 2$ table) was done to test the significant level $(p<0.05)$ for sex differences on thinness among the studied children, if any.

\section{RESULTS}

Table 3 represents the prevalence of thinness (low BMI for age, grade I, II and III) of the children. The thinness was calculated with the help of the newly proposed cut off points by Cole et al. [8], (Table 2). The overall (age combined) prevalence of thinness among the boys was slightly higher (83.2\%) in comparison to the prevalence of thinness among the girls (81.5\%). The prevalence of thinness was higher in case of lower age group children among both boys and girls and it gradually decreases with the increase of age. Boys of the age groups 5 and 6 years were much severely undernourished (about $93 \%$ ) than the girls of the same age groups (about $88 \%$ and $85 \%$ respectively).

Table 1: Distribution of Primary School Children by Age and Sex

\begin{tabular}{|c|c|c|c|}
\hline \multirow{2}{*}{ Age groups in years } & \multicolumn{2}{|c|}{ Sex } & \multirow{2}{*}{ Total } \\
\cline { 2 - 4 } & Boys & Girls & 32 \\
\hline \hline 5 & 15 & 17 & 94 \\
\hline 6 & 47 & 47 & 129 \\
\hline 7 & 58 & 71 & 151 \\
\hline 8 & 73 & 78 & 126 \\
\hline 9 & 68 & 58 & 71 \\
\hline 10 & 39 & 32 & 15 \\
\hline 11 & 4 & 11 & 618 \\
\hline Total & 304 & 314 & \\
\hline
\end{tabular}

Table 2: The BMI (Wt/Ht ${ }^{2}$ ) Cut-off Points for Thinness Grades III, II, and I for 5-11 Years Children as Proposed by Cole et al. (2007)

\begin{tabular}{|c|c|c|c|c|c|c|}
\hline \multirow{2}{*}{$\begin{array}{c}\text { Ages } \\
\text { (years) }\end{array}$} & \multicolumn{3}{|c|}{ Boys } & \multicolumn{3}{|c|}{ Girls } \\
\hline & Grade III & Grade II & Grade I & Grade III & Grade II & Grade I \\
\hline 5 & 12.66 & 13.31 & 14.21 & 12.50 & 13.09 & 13.94 \\
\hline 6 & 12.50 & 13.15 & 14.07 & 12.32 & 12.93 & 13.82 \\
\hline 7 & 12.42 & 13.08 & 14.04 & 12.26 & 12.91 & 13.86 \\
\hline 8 & 12.42 & 13.11 & 14.15 & 12.31 & 13.00 & 14.02 \\
\hline 10 & 12.66 & 13.45 & 14.64 & 12.64 & 13.43 & 14.61 \\
\hline 11 & 12.89 & 13.72 & 14.97 & 12.95 & 13.79 & 15.05 \\
\hline
\end{tabular}


Table 3: Prevalence of Thinness among the Studied Primary School Children

\begin{tabular}{|c|c|c|c|c|c|c|c|c|c|c|}
\hline \multirow{2}{*}{$\begin{array}{c}\text { Age } \\
\text { (years) }\end{array}$} & \multicolumn{5}{|c|}{ Boys - Thinness } & \multicolumn{5}{|c|}{ Girls - Thinness } \\
\hline & Grade III & Grade II & Grade I & Total & Normal & Grade III & Grade II & Grade I & Total & Norma \\
\hline 5 & $\begin{array}{c}7 \\
(46.7)\end{array}$ & $\begin{array}{c}3 \\
(20.0)\end{array}$ & $\begin{array}{c}4 \\
(26.7)\end{array}$ & $\begin{array}{c}14 \\
(93.3)\end{array}$ & $\begin{array}{c}1 \\
(6.7)\end{array}$ & $\begin{array}{c}9 \\
(52.9)\end{array}$ & $\begin{array}{c}5 \\
(29.4)\end{array}$ & $\begin{array}{c}1 \\
(5.9)\end{array}$ & $\begin{array}{c}15 \\
(88.2)\end{array}$ & $\begin{array}{c}2 \\
(11.8)\end{array}$ \\
\hline 6 & $\begin{array}{c}12 \\
(25.5)\end{array}$ & $\begin{array}{c}21 \\
(44.7)\end{array}$ & $\begin{array}{c}11 \\
(23.4)\end{array}$ & $\begin{array}{c}44 \\
(93.6)\end{array}$ & $\begin{array}{c}3 \\
(6.4)\end{array}$ & $\begin{array}{c}23 \\
(48.9)\end{array}$ & $\begin{array}{c}7 \\
(14.9)\end{array}$ & $\begin{array}{c}10 \\
(21.3)\end{array}$ & $\begin{array}{c}40 \\
(85.1)\end{array}$ & $\begin{array}{c}7 \\
(14.9)\end{array}$ \\
\hline 7 & $\begin{array}{c}16 \\
(27.6)\end{array}$ & $\begin{array}{c}13 \\
(22.4)\end{array}$ & $\begin{array}{c}18 \\
(31.0)\end{array}$ & $\begin{array}{c}47 \\
(81.0)\end{array}$ & $\begin{array}{c}11 \\
(19.0)\end{array}$ & $\begin{array}{c}22 \\
(31.0)\end{array}$ & $\begin{array}{c}22 \\
(31.0)\end{array}$ & $\begin{array}{c}18 \\
(25.4)\end{array}$ & $\begin{array}{c}62 \\
(87.3)\end{array}$ & $\begin{array}{c}9 \\
(12.7)\end{array}$ \\
\hline 8 & $\begin{array}{c}16 \\
(21.9)\end{array}$ & $\begin{array}{c}16 \\
(21.9)\end{array}$ & $\begin{array}{c}32 \\
(43.8)\end{array}$ & $\begin{array}{c}64 \\
(87.7)\end{array}$ & $\begin{array}{c}9 \\
(12.3)\end{array}$ & $\begin{array}{c}17 \\
(21.8)\end{array}$ & $\begin{array}{c}28 \\
(35.9)\end{array}$ & $\begin{array}{c}21 \\
(26.9)\end{array}$ & $\begin{array}{c}66 \\
(84.6)\end{array}$ & $\begin{array}{c}12 \\
(15.4)\end{array}$ \\
\hline 9 & $\begin{array}{c}12 \\
(17.6)\end{array}$ & $\begin{array}{c}16 \\
(23.5)\end{array}$ & $\begin{array}{c}24 \\
(35.3)\end{array}$ & $\begin{array}{c}52 \\
(76.5)\end{array}$ & $\begin{array}{c}16 \\
(23.5)\end{array}$ & $\begin{array}{c}15 \\
(25.9)\end{array}$ & $\begin{array}{c}12 \\
(20.7)\end{array}$ & $\begin{array}{c}16 \\
(27.6)\end{array}$ & $\begin{array}{c}43 \\
(74.1)\end{array}$ & $\begin{array}{c}15 \\
(25.9)\end{array}$ \\
\hline 10 & $\begin{array}{c}8 \\
(20.5)\end{array}$ & $\begin{array}{c}10 \\
(25.6)\end{array}$ & $\begin{array}{c}11 \\
(28.2)\end{array}$ & $\begin{array}{c}29 \\
(74.4)\end{array}$ & $\begin{array}{c}10 \\
(25.6)\end{array}$ & $\begin{array}{c}5 \\
(15.6)\end{array}$ & $\begin{array}{c}15 \\
(46.9)\end{array}$ & $\begin{array}{c}3 \\
(9.4)\end{array}$ & $\begin{array}{c}23 \\
(71.9)\end{array}$ & $\begin{array}{c}9 \\
(28.1)\end{array}$ \\
\hline 11 & $\begin{array}{c}2 \\
(50.0)\end{array}$ & $\begin{array}{c}1 \\
(25.0)\end{array}$ & - & $\begin{array}{c}3 \\
(75.0)\end{array}$ & $\begin{array}{c}1 \\
(25.0)\end{array}$ & $\begin{array}{c}5 \\
(45.4)\end{array}$ & $\begin{array}{c}2 \\
(18.2)\end{array}$ & - & $\begin{array}{c}7 \\
(63.6)\end{array}$ & $\begin{array}{c}4 \\
(36.4)\end{array}$ \\
\hline Total & $\begin{array}{c}73 \\
(24.0)\end{array}$ & $\begin{array}{c}80 \\
(26.3)\end{array}$ & $\begin{array}{c}100 \\
(32.9)\end{array}$ & $\begin{array}{c}253 \\
(83.2)\end{array}$ & $\begin{array}{c}51 \\
(16.8)\end{array}$ & $\begin{array}{c}96 \\
(30.5)\end{array}$ & $\begin{array}{c}91 \\
(29.0)\end{array}$ & $\begin{array}{c}69 \\
(22.0)\end{array}$ & $\begin{array}{c}256 \\
(81.5)\end{array}$ & $\begin{array}{c}58 \\
(18.5)\end{array}$ \\
\hline
\end{tabular}

Percentages are given in the parentheses.

Table 4: Comparison of the Prevalence of Thinness (by BMI) among the Children of Different Studies

\begin{tabular}{|c|c|c|}
\hline Studied children & Prevalence (\%) & Reference \\
\hline 1. 6-14 yr, Bankura, W.B. & 23.1 & Biswas et al., 2008 \\
\hline 2. 5-10 yr, Purba Midnapur, & 62.2 & Chakraborty and Bose, 2009 \\
\hline 3. 6-14 yr, Assam & 53.9 & Medhi et al., 2007 \\
\hline 4. 2-13 yr, Paschim Midnapur & 67.2 & Bisai et al., 2010 \\
\hline 5. 5-12 yr, Darjeeling, W.B. & 69.4 & Mondal and Sen, 2010 \\
\hline 6. 5-11 yr, Bali-Gram Panchayat, Arambag, W.B. & 82.4 & Present study \\
\hline
\end{tabular}

Considering the gradation of the thinness, the rate of grade III (30.5\%) was greater among the girls than others while among the boys it was higher in grade I $(32.9 \%)$ category. It indicates the severity of thinness was much more among the girls than the boys. There was no significant sex difference between the two sexes.

Table 4 depicts the prevalence of thinness among the children of various studies including the present one. It is evident from the table that, the highest rate $(82.4 \%)$ of thinness is noticed among the children of Bali-Gram Panchayat followed by the children of Darjeeling District, W.B. (69.4\%); [12], 67.2\% among the children of Paschim Midnapur [13]. Assamese children showed comparatively lesser degree of thinness (53.9\%); [14] than the present one. 6-14 year children of Bankura revealed the lowest prevalence (23.1\%) of thinness [15].

Table 5: Comparison of the Prevalence of Thinness (by BMI) among the Children of Present Study with that of the Previous Study in the Same Area

\begin{tabular}{|c|c|c|}
\hline Studied children & Prevalence (\%) & Reference \\
\hline \hline $\begin{array}{c}\text { 1. 2-6 years (ICDS) children of Bali-Gram Panchayat, } \\
\text { Arambag, W.B. , India. }\end{array}$ & 85.2 & Mandal et al., 2009 [11] \\
\hline $\begin{array}{c}\text { 2. 5-11 years primary school children of Bali-Gram } \\
\text { Panchayat, Arambag, W.B., India. }\end{array}$ & 82.4 & Present study \\
\hline
\end{tabular}


The children of the area are getting Mid Day Meal supplied through the school authorities which is comparatively better but not highly satisfactory. But when we compare the prevalence of thinness (Table 5) between the children of the present study and the ICDS children (11) of the same area, it is revealed that, no satisfactory improvement has been indicated, although, slight improvement in the rate of thinness is evident (82.5\% in comparison to $85.2 \%)$.

\section{DISCUSSION}

Any major deviation in the nutrient intake either in quality or in quantity from its requirement can also affect growth and life span in a number of ways, particularly in the later period/growth [16]. The underfed still outnumbered in the developing world among Asian, African and Latin American populations. In spite of the economic development in the region, undernutrition remains an important public problem in many Asian countries [17]. Despite the availability of surplus food grains in India and in South Asia, the region is still facing high levels of hunger [18]. Among the school children aged 5-10 years from Purba Midnapore District, West Bengal, the prevalence of thinness was $62.2 \%$ [19] which was much lower than the present one. Medhi and others [20] reported much better situation of nutritional condition among the 6-14 years school children of Dibrugarh district, Assam, India where the overall rate of thinness was $53.2 \%$. A noteworthy point was that all the studies reported that both sexes had more-or-less similar rates of thinness [13]. There were several studies for assessing undernutrition based on thinness where reported lower prevalence of undernutrition than the present study.

The prevalence of undernutrition as measured by thinness was significantly higher than the national level scenario. In spite of the Mid Day Meal scheme which is running for more than 20 years, the result is dissatisfactory. Since the overwhelming majority of the Indian population inhabit rural areas where the rates of childhood undernutrition are very high, such studies should focus on rural primary school children. Valuable health and nutritional promotion programs can be formulated based on the findings of these researches with the ultimate objective of decreasing childhood undernutrition in the area as well as in other places of the country.

\section{CONFLICT OF INTEREST}

None.

\section{ACKNOWLEDGEMENTS}

All subjects who participated in the study are gratefully acknowledged. Special thanks are due to the authorities of the Primary schools.

\section{RRFERENCES}

[1] Pelletier DL. The relationship between child anthropometry and mortality in developing countries: implications for policy, programs and future research. J Nutr 1994; 124: 2047S2081S.

[2] Scrimshaw NS. The New Paradigm of Public Health Nutrition. Am J Pub Health 1995; 85: 622-624.

[3] Economic Survey, Govt. of India, 2002-2003; pp. 229-33.

[4] Shah PU, Patel HJ. A study about prevalence of undernutrition among slum children of 0-60 months of age of Mehsana city. International Research Journal 2009; Vol. II, Issue-7: 84-85.

[5] WHO Expert Committee on Comprehensive School Health Education and Promotion. Promoting Health through Schools. 1997; Report of a Geneva, WHO Technical Series, No. 870.

[6] WHO. Physical status: the use and interpretation of anthropometry. Report of a WHO Expert Committee. Technical Report Series No. 854. World Health Organization, 1995; Geneva, Switzerland.

[7] WHO Multicentre Growth Reference Study Group. WHO Child Growth Standards: Length / height-for-age, weight-for-age, weight-for-length, weight-for-height and body mass index-for-age: Methods and development. Geneva: World Health Organization, 2006; Available at: www.who.int/childgrowth/standards/technical report/en/. Acess date: May 22, 2008.

[8] Cole TJ, Flegal KM, Nicholls D, Jackson AA. Body mass index cut offs to define thinness in children and adolescents: international survey. BMJ 2007; 335: 194.

[9] Lohman TG, Roche AF, Martorell R. Anthropometric Standardization Reference Manual. Chicago: Human Kinetics Books 1988.

[10] Ulijaszek SJ, Kerr DA. Anthropometric measurement error and the assessment of nutritional status. Brit J Nutr 1988; 82 : 165-177.

[11] Mandal GC, Bose $\mathrm{K}$ and Bisai S. Thinness among rural children in Bengal. Indian J Pediatr 2009; 76: 817-819.

[12] Mondal N, Sen J. Thinness is a major underlying problem among Indian children. Journal of Tropical Pediatrics 2010 (http://tropij.oxfordjournals.org/content/early/2010/03/07/tropij .fmqo14.abstract, accessed on 27.03.2011)

[13] Bisai S, Ghosh, De GK, Bose K. Very high prevalence of thinness among Kora - Mudi tribal children of paschim Midnapur Dist. Of West Bengal, India. EJBS 2010; (1): 43-45.

[14] Medhi GK, Barua A, Mahanta. Growth and nutritional status of school age children (6-14 years) of Tea Garden workers of Assam. J Hum Ecol 2007; 19: 83-85.

[15] Biswas S, Bose K, Bisai S, Chakraborty R. Prevalence of thinne among rural Bengalee pre-school children in Chapra, Nadia District, West Bengal, India. Malay J Nutr 2009; 15 : 155-164.

[16] Gopalan C, Ramsastri BV, Balasubramanian SC Recommended Dietary Allowances for Indians, ICMR, Hyderabad 1989

[17] Wickramasinghe VP, Lamabadusuriya SP, Atapattu N Sathyadas G, Uruparanantha S, Karunarathne P. 'Nutritional status of school children in an urban area of Sri Lanka', Ceylon Med J 2004; 49(4): 114-118. 
[18] Gupta SP. India Vision 2020, Report of the Committee on India Vision 2020, Planning Commission, Government of India, New Delhi, 2004; pp. 30-35.

[19] Chakraborty R, Bose K. Very high prevalence of thinness using new international body mass index cut off points among the 5-10 year old school children of Nandigram, West Bengal, India. J Res Med Sci 2009; 14: 129-133.

[20] Medhi GK, Barua A, Mahanta J. 'Growth and nutritional status of school age children (6-14 years) of tea garden worker of Assam'. J Hum Ecol 2006; 19(2): 83-85. 